\title{
Ante-mortem and post-mortem tuberculosis diagnostics in three European Bison (Bison bonasus caucasicus) from the enclosure in Bukowiec in the Bieszczady National Park in Poland
}

\author{
KRZYSZTOF ANUSZ, BLANKA ORŁOWSKA, MONIKA KRAJEWSKA-WĘDZINA*, \\ EWA AUGUSTYNOWICZ-KOPEĆ ${ }^{* *}$, MICHAŁ KRZYSIAK ${ }^{* * *}$, WOJCIECH BIELECKI ${ }^{* * * *}$, \\ LUCJAN WITKOWSKI*****, MIROS $Ł$ AW WELZ ${ }^{* \star * * * *}$, JERZY KITA***** \\ Department of Food Hygiene and Public Health Protection, Faculty of Veterinary Medicine, \\ Warsaw University of Life Sciences (SGGW), Nowoursynowska 166, 02-787 Warsaw, Poland \\ *Department of Microbiology, National Veterinary Institute - National Research Institute in Puławy, \\ Al. Partyzantów 57, 24-100 Puławy, Poland \\ **Department of Microbiology, Institute of Tuberculosis and Lung Diseases, Płocka 26, 01-138 Warsaw \\ *** National park in Bialowieza
}

****Division of Pathology of Exotic, Laboratory and Non-domesticated Animals and Fish, Faculty of Veterinary Medicine, Warsaw University of Life Sciences (SGGW), Ciszewskiego 8, 02-787 Warsaw, Poland

***** Laboratory of Epidemiology and Veterinary Economics, Faculty of Veterinary Medicine, Warsaw University of Life Sciences (SGGW), Nowoursynowska 159c, 02-776 Warsaw, Poland ******Provincial Veterinary Inspectorate, Piotra Sciegiennego 6 A, 38-400 Krosno, Poland

Anusz K., Orłowska B., Krajewska-Wędzina M., Augustynowicz-Kopeć E., Krzysiak M., Bielecki W., Witkowski L., Welz M., Kita J.

Ante-mortem and post-mortem tuberculosis diagnostics in three European Bison (Bison bonasus caucasicus) from the enclosure in Bukowiec in the Bieszczady National Park in Poland

\section{Summary}

The ante-mortem diagnostics of tuberculosis in wildlife constitutes a major problem due to the difficulties in collecting samples for examination. Therefore, tuberculosis in free-living animals is usually diagnosed post mortem. Ante-mortem examinations for bovine tuberculosis (BTB) were conducted in three European bison living in an acclimatisation enclosure in Bukowiec in the Bieszczady National Park in Poland. The reason for performing these examinations was the documented contact between the aforementioned animals and tuberculous European bison from a free-living herd present in the area. The three European bison were pharmacologically immobilised. Next, their blood samples were collected for immunological studies (interferon-gamma release assays), complete blood count and blood biochemistry tests. Moreover, bronchoalveolar lavage (BAL) fluid from the lower respiratory tract, two nasal cavity swabs and one throat swab were taken from each animal. Tuberculin testing was also performed. The findings of all these examinations indicated the possible infection of the European bison with the tubercle bacillus. Ultimately, the decision was taken to euthanize the animals.

Keywords: European bison (Bison bonasus caucasicus), bovine tuberculosis, Mycobacterium tuberculosis complex

The acclimatisation enclosure in Bukowiec is situated in the Lutowiska commune, in the territory of the Bieszczady National Park. It was founded for the European bison from the "Upper San" herd, which inhabits mainly the territory of the Bieszczady National Park and the Stuposiany Forest Inspectorate. The enclosure was established to reduce the risk of poaching by catching some European bison from this herd and equipping them with satellite telemetry collars for constant herd monitoring. In 2008, the Bieszczady National Park submitted a grant application to finance the construction of a catching pen and the purchase of necessary equipment. The application was approved by the Voivodeship Nature Conservator in Rzeszów and the Coordinator of the European Bison Conservation Programme. In view of the low genetic diversity of 
herds inhabiting the Bieszczady Mountains, the decision was taken to enhance the population of European bison living in the Bieszczady Mountains with new genetic material and to use the enclosure in Bukowiec to acclimatise animals transferred from other European centres. In September 2011, upon the consent of the General Director for Environmental Protection, two European bison (one cow and one bull) were transferred to the acclimatisation enclosure in Bukowiec in the Bieszczady National Park from a zoo in Prague in the Czech Republic. One month later, another cow was transferred. According to the original plan, the animals were to be released after a three-month acclimatisation period spent in the enclosure. They were, however, in the middle of their intensive growth and too young to be released. Thus, it was impossible to equip them with satellite telemetry collars. The release of the European bison from the enclosure in Bukowiec was postponed three times because of the confirmed occurrence of bovine tuberculosis (BTB) in the European bison herd living in the Upper San Valley.

In 2013, three European bison living in the acclimatisation enclosure in Bukowiec were subjected to antemortem examinations for bovine tuberculosis (BTB) at the request of the Bieszczady National Park, upon the decision of the General Director for Environmental Protection and in consultation with the Subcarpathian Voivodeship Veterinary Officer. These examinations were supervised by the Department of Food Hygiene and Public Health Protection, Faculty of Veterinary Medicine, Warsaw University of Life Sciences. They were carried out because of documented contacts of the animals with free-living European bison in the Stuposiany Forest Inspectorate and the Lutowiska Forest Inspectorate, which had been closed upon the occurrence of bovine tuberculosis (BTB) caused by Mycobacterium caprae (7).

Bovine tuberculosis (BTB) is a chronic and wasting bacterial disease, a zoonotic disease, the aetiological agents of which are bovine tubercle bacilli, Mycobacterium bovis and Mycobacterium caprae, classified within the Mycobacterium tuberculosis (MTBC) complex (14). The ante-mortem diagnostics of tuberculosis in wildlife constitutes a major problem due to the difficulties in collecting samples for examination (11). Therefore, tuberculosis in freeliving animals is usually diagnosed post mortem (13). However, in the event of bovine tuberculosis (BTB) suspicion in protected and genetically valuable species, it is recommended to perform reliable ante-mortem examinations (2). This study researched ante-mortem tuberculosis diagnostics in three European bison (Bison bonasus caucasicus).

\section{Material and methods}

The study included two female and one male European bison (Bison bonasus caucasicus) of the lowland-Caucasian line, born in a zoo in Prague, Czech Republic, in 2009, which were marked with the following numbers: $1\left({ }^{\text {đ) }}\right.$, 2 ()), 3 (ㅇ).

Ante-mortem diagnostics. The animals were pharmacologically immobilised to restrain them. Their weight was estimated primarily on the basis of data on the biology of European bison and data obtained by the weighting of culled animals or fallen stock $(8,12)$. As recommended by the literature, a dose of two combined active substances, etorphine hydrochloride and xylazine, was administered (9). Prior to tuberculin testing, blood samples had been collected from the three European bison for immunological studies (interferon-gamma release assays), as well as complete blood count and blood biochemistry tests. At the same time, bronchoalveolar lavage (BAL) fluid from the lower respiratory tract, two nasal cavity swabs and one throat swab were taken from each animal. The tuberculin testing was performed in accordance with the Instructions of the Chief Veterinary Officer, which apply to cattle (comparative tuberculin tests), with the use of the following products: Bovitubal 28000 series 895718 and Avitubal 28000 series 475718 , in the amount of $0.1 \mathrm{ml}$ (2,800 units of tuberculin). The tuberculin administration sites were carefully shaven to observe the reaction. The results of tuberculin tests were read from a distance of 2 meters after 72 hours. It was impossible to re-measure the skin reaction for technical reasons, as the re-immobilisation of the animals would entail additional costs. Allergic reactions were recorded in a digital format.

Interferon-gamma release assays were performed with the Bovigam ${ }^{\circledR}$ test (Prionics, Switzerland) intended for antemortem tuberculosis diagnostics in ruminants, in line with the recommendations of the manufacturer. Apart from the tuberculin test, the interferon-gamma release assay has also been approved by the European Union for the ante-mortem diagnostics of bovine tuberculosis (6). Its aim is to detect interferon-gamma secreted in vitro by the leukocytes of an infected animal $(3,4,16)$. It is performed with the use of whole blood samples collected into tubes containing lithium heparin or any other anticoagulant, which are then incubated with tuberculin in an incubator $\left(37^{\circ} \mathrm{C} ; \pm 2^{\circ} \mathrm{C}\right)$. Next, the ELISA test is performed to measure the levels of interferon-gamma released. Across the European Union, the ELISA test is currently regarded as an auxiliary method, which is useful particularly for the examination of wildlife. Therefore, with reference to the application of interferongamma release assays in cattle, the positive result of these assays combined with a negative tuberculin test may serve as a basis for considering an animal as infected (6). In 1991, interferon-gamma release assays were approved as official diagnostic tests for bovine tuberculosis in Australia. Several years later, these assays also became the official diagnostic test for bovine tuberculosis in New Zealand (15).

Microbiological studies of samples collected from the lower and upper respiratory tracts were conducted by three different methods. The culture tests were performed using Löwenstein-Jensen solid medium, Middlebrook liquid medium and an automatic system for the cultivation of tubercle bacilli, Bactect MGIT 960 (Becton Dickinson, USA). In the last stage, tests were performed with the genetic system BD ProbeTec ${ }^{\mathrm{TM}} \mathrm{ET}^{\circledR}$ (Becton Dickinson, USA), which makes it possible to detect the DNA of the 
Mycobacterium tuberculosis complex directly in clinical material. The system identifies the IS 6110 insertion sequence, which is observed exclusively in the M. tuberculosis complex (MTBC), in the number of 1-20 copies in one genome. The amplification, i.e. duplication, of the genetic material of tubercle bacilli, takes place in special incubation wells. Each process of DNA duplication contains the Internal Amplification Control (IAC), which makes it possible to identify inhibitors in the material tested. The enzyme used in this reaction is DNA polymerase.

Post-mortem diagnostics. The laboratory diagnostics of bovine tuberculosis is carried out in accordance with the instructions for the laboratory diagnostics of bovine tuberculosis issued by the National Veterinary Institute National Research Institute in Puławy (10). It comprises the following stages: anatomical pathology testing of tissue specimens, microscopic studies and culture testing on solid Stonebrink and Petragnani media. Pursuant to the Regulation of the Minister of Agriculture and Rural Development of 23 November 2004 on the eradication of tuberculosis in cattle (Polish Journal of Laws, No. 282, Item 2813, as amended), the following lymph nodes were collected from each European bison for microbiological testing: parapharyngeal, bronchial, mediastinal, mandibular, mesenteric and liver hilum lymph nodes.

\section{Results and discussion}

Tuberculin skin test. European bison no. 1 showed a positive reaction to avian tuberculin: confined oedema with a diameter of about 3-4 cm clearly rising above the skin surface, as well as a positive reaction to bovine tuberculin: diffuse oedema with a diameter of about $4 \mathrm{~cm}$ (not rising above the skin surface). In a comparative assessment the findings were interpreted as positive and indicative of the infection of the European bison male with the bovine tubercle bacillus. European bison no. 2 showed a positive reaction to avian tuberculin: confined oedema with a diameter of about $2 \mathrm{~cm}$ clearly rising above the skin surface, as well as a positive reaction to bovine tuberculin, clearly outlined and minimally rising above the skin surface with a diameter of about $2 \mathrm{~cm}$. In a comparative assessment the findings were interpreted as dubious and indicative of the possible infection of the European bison female with the bovine tubercle bacillus. European bison no. 3 showed a positive reaction to avian tuberculin: confined oedema with a diameter of about $2-3 \mathrm{~cm}$ clearly rising above the skin surface, and no reaction to bovine tuberculin. In a comparative assessment the results were interpreted as negative.

Complete blood count and blood biochemistry tests. In all the animals tested, a relative and, to a lesser extent, absolute neutrocytosis with degenerative neutrophilia and a decreased percentage of lymphocytes were observed. There were no deviations of blood biochemistry parameters from reference values (1). The red blood cell picture was not abnormal. The results of complete blood count and blood biochemistry tests are presented in Tab. 1, 2 and 3.
Tab. 1. Complete blood count test results

\begin{tabular}{|c|c|c|c|c|}
\hline \multirow{2}{*}{$\begin{array}{l}\text { Complete blood } \\
\text { count parameters }\end{array}$} & \multirow{2}{*}{ Unit } & \multicolumn{3}{|c|}{ Results } \\
\hline & & Bison 1 & Bison 2 & Bison 3 \\
\hline WBC & $10^{\wedge} \mathrm{g} / \mathrm{l}$ & 7.33 & 7.46 & 6.51 \\
\hline LYM & $10^{\wedge} 9 / /$ & 2.58 & 2.36 & 2.12 \\
\hline MID & $10^{\wedge} 9 / /$ & 0.33 & 0.24 & 0.33 \\
\hline GRA & $10^{\wedge} 9 / /$ & 4.42 & 4.85 & 4.05 \\
\hline LY\% & $\%$ & 35.2 & 31.7 & 32.6 \\
\hline MI\% & $\%$ & 4.5 & 3.2 & 5.1 \\
\hline GR\% & $\%$ & 60.3 & 65.1 & 62.2 \\
\hline RBC & $10^{\wedge} 12 / /$ & 7.02 & 6.56 & 6.95 \\
\hline HGB & $\mathrm{g} / \mathrm{dl}$ & 12.0 & 10.9 & 11.9 \\
\hline HСT & $\%$ & 36.13 & 34.21 & 37.59 \\
\hline MCV & $\mathrm{fl}$ & 51 & 52 & 54 \\
\hline MCH & $\mathrm{pg}$ & 17.1 & 16.7 & 17.1 \\
\hline МСНС & $\mathrm{g} / \mathrm{dl}$ & 33.2 & 31.9 & 31.5 \\
\hline RDW & $\%$ & 17.9 & 18.9 & 19.9 \\
\hline PLT & $10^{\wedge} 9 / /$ & 99 & 383 & 140 \\
\hline РCT & $\%$ & 0.06 & 0.26 & 0.10 \\
\hline MPV & $\mathrm{fl}$ & 6.1 & 6.9 & 7.4 \\
\hline PDW & $\%$ & 32.6 & 35.3 & 36.0 \\
\hline
\end{tabular}

Tab. 2. White blood cell picture

\begin{tabular}{|l|c|c|c|}
\hline \multicolumn{1}{|c|}{ WBC Picture } & \multicolumn{3}{|c|}{ Results } \\
& Bison 1 & Bison 2 & Bison 3 \\
\hline Band neutrophils\% & 4 & 10 & 3 \\
\hline Segmented neutrophils\% & 58 & 55 & 64 \\
\hline Eosinophils & 0 & 3 & 3 \\
Lymphocytes\% & 36 & 31 & 28 \\
Monocytes\% & 2 & 1 & 2 \\
Basophils\% & 0 & 0 & 0 \\
\hline
\end{tabular}

Tab. 3. Blood biochemistry results

\begin{tabular}{|l|c|c|c|c|}
\hline $\begin{array}{c}\text { Serum biochemistry } \\
\text { parameters }\end{array}$ & Unit & \multicolumn{3}{|c|}{ Results } \\
\hline AST & U/l & 81.0 & 89.8 & 87.1 \\
\hline ALT & U/l & 20.9 & 34.8 & 34.0 \\
\hline AP & U/l & 58.4 & 65.7 & 51.2 \\
\hline Creatinine & $\mathrm{mg} / \mathrm{dl}$ & 1.1 & 1.1 & 1.22 \\
\hline Urea & $\mathrm{mg} / \mathrm{dl}$ & 22.8 & 24.6 & 27.6 \\
\hline Total protein & $\mathrm{g} / \mathrm{l}$ & 56.0 & 63.8 & 60.4 \\
\hline Albumins & $\mathrm{g} / \mathrm{l}$ & 33.7 & 32.1 & 33.9 \\
\hline CPK & $\mathrm{U} / \mathrm{l}$ & 181.5 & 353.7 & 189.0 \\
\hline GGTP & $\mathrm{U} / \mathrm{l}$ & 17.8 & 21.1 & 25.6 \\
\hline Bilirubin & $\mathrm{mg} / \mathrm{dl}$ & 0.24 & 0.21 & 0.26 \\
\hline Ca & $\mathrm{mg} / \mathrm{dl}$ & 9.6 & 9.6 & 10.4 \\
\hline $\mathrm{P}$ & $\mathrm{mg} / \mathrm{dl}$ & 3.6 & 3.8 & 3.1 \\
\hline $\mathrm{Mg}$ & $\mathrm{mg} / \mathrm{dl}$ & 2.2 & 2.0 & 2.2 \\
\hline $\mathrm{K}$ & $\mathrm{mmol} / \mathrm{l}$ & 5.28 & 4.81 & 5.38 \\
\hline $\mathrm{Na}$ & $\mathrm{mmol} / \mathrm{l}$ & 125.7 & 126.5 & 127.3 \\
\hline $\mathrm{Cl}$ & $\mathrm{mmol} / \mathrm{l}$ & 99.6 & 98.6 & 98.5 \\
\hline
\end{tabular}


Interferon-gamma release assay. In the blood plasma samples collected from European bison no. 1 and 2, the results indicated an increased interferongamma level following the stimulation with bovine and avian tuberculin. According to the manufacturer's guidelines, the results of the examination of these samples for tuberculosis should be interpreted as negative primarily because of the very high values obtained after the stimulation with avian tuberculin (similarly as in the comparative tuberculin test). However, the values obtained from the samples stimulated with bovine tuberculin were so high that the possibility of contact of these animals with avian and bovine tubercle bacilli could not be excluded. Regarding European bison no. 3, the levels of interferon-gamma released after the stimulation with bovine and avian tuberculin unambiguously indicated a negative result, which agreed with the result of the comparative tuberculin test performed in this animal.

Isolation of tubercle bacilli and molecular testing of specimens from the upper and lower respiratory tracts. No tubercle bacilli were cultured from the bronchoalveolar lavage (BAL) fluid collected from the lower respiratory tract, nor from the nasal cavity and throat swabs taken from the animals. However, molecular tests performed directly on the samples of the bronchoalveolar lavage (BAL) fluid from the lower respiratory tract of European bison no. 1 and the nasal cavity swabs taken from European bison no. 2 and 3 confirmed the presence of genetic material of tubercle bacilli belonging to the MTBC complex.

Ultimately, in 2014, the decision was taken to euthanise the three animals, based on the results obtained and upon the consent of the Minister of Environmental Protection and the General Director for Environmental Protection.

Necropsy and isolation of tubercle bacilli from lymph nodes. None of the three European bison demonstrated anatomo-pathological lesions typical of bovine tuberculosis. Their lymph nodes were not abnormal. No acid-proof bovine tubercle bacilli were observed in culture tests.

The findings of ante-mortem and post-mortem diagnostics are presented in Tab. 4. The results of the traditional tuberculin test, i.e. the comparative tuberculin test, is of paramount importance in the ante-mortem diagnostics of bovine tuberculosis. The detection of the genetic material of tubercle bacilli and their isolation from samples collected ante mortem is not necessary to recognise the animals as infected. On the basis of the results of comparative tuberculin tests, European bison male no. 1 was considered to be infected with the bovine tubercle bacillus. Furthermore, this was confirmed by the very high interferongamma levels in the blood plasma samples collected from this animal. The infection was also confirmed by the presence of genetic material of tubercle bacilli belonging to the MTBC complex in the bronchioalveolar lavage (BAL) fluid from the lower respiratory tract. The result of a comparative tuberculin test in European bison female no. 2 was considered dubious, indicating merely the possibility of infection with the bovine tubercle bacillus. However, given the result of interferon-gamma release assay (high interferon-gamma levels in blood plasma) and the presence of genetic material of tubercle bacilli belonging to the MTBC complex in the nasal cavity swab, it was necessary to recognise this animal, too, as infected with the bovine tubercle bacillus. The result of the comparative tuberculin test performed in European bison female no. 3 was assessed as negative, which indicated the absence of infection. This result was confirmed by the negative interferon-gamma release assay. At the same time, however, the genetic material of tubercle bacilli belonging to the MTBC complex was identified in the nasal cavity swab taken from this animal, which should tighten up the assessment of the health status of the animal. All the more so as the results of complete blood count tests performed in all animals, including European bison female no. 3, suggested an ongoing infection process at its early stage. The relative and absolute neutrocytosis, degenerative neutrophilia and decreased percentage of lymphocytes may prove that the animal had not developed a fully active reaction to the infection (which may have been at a relatively early stage, as no deviations from reference values were observed in blood biochemistry results). A particularly strong anergy of lymphocytes in European bison female no. 3 cannot be ruled out, which may have been related to the mechanism of immune tolerance - in this case, tolerance towards the antigens of Mycobacterium bovis and, to a lesser extent, the antigens of Mycobacterium avium (an allergic reaction to the intradermal administration of avian tuberculin was

Tab. 4. Results of tuberculin skin tests, interferon-gamma release assays, molecular tests of bronchoalveolar lavage (BAL) fluid collected from the lower respiratory tract and microbiological tests of lymph nodes

\begin{tabular}{|c|c|c|c|c|}
\hline \multirow{2}{*}{\multicolumn{2}{|c|}{ Test Type }} & \multicolumn{3}{|c|}{ Results } \\
\hline & & Bison 1 & Bison 2 & Bison 3 \\
\hline \multicolumn{5}{|c|}{ Ante-mortem examinations } \\
\hline \multicolumn{2}{|c|}{ Tuberculin skin test } & Positive & Dubious & Negative \\
\hline \multicolumn{2}{|c|}{ Interferon-gamma release assay } & Positive & Positive & Negative \\
\hline \multicolumn{2}{|c|}{$\begin{array}{l}\text { Isolation of tubercle bacilli from bronchoalveolar } \\
\text { lavage (BAL) fluid collected from lower respiratory } \\
\text { tract, nasal cavity and throat swabs }\end{array}$} & Negative & Negative & Negative \\
\hline \multirow[t]{3}{*}{$\begin{array}{l}\text { Molecular } \\
\text { tests }\end{array}$} & $\begin{array}{l}\text { Bronchoalveolar lavage (BAL) fluid } \\
\text { collected from lower respiratory tract }\end{array}$ & Positive & Negative & Negative \\
\hline & Swabs from nasal cavity & Negative & Positive & Positive \\
\hline & Swabs from throat & Negative & Negative & Negative \\
\hline \multicolumn{5}{|c|}{ Post-mortem examinations } \\
\hline \multicolumn{2}{|l|}{ Necropsy } & Negative & Negative & Negative \\
\hline \multicolumn{2}{|c|}{ Isolation of tubercle bacilli from lymph nodes } & Negative & Negative & Negative \\
\hline
\end{tabular}


observed, but no decrease in interferon-gamma serum levels in response to the stimulation of lymphocytes with avian tuberculin).

The results of tuberculin tests using avian tuberculin (European bison no. 1, 2, 3) combined with the results of the interferon-gamma release assay (European bison no. 1,2) indicate the infection of the animals with atypical Mycobacterium avium tubercle bacillus as well. The above should be taken into account in interpreting the interferon-gamma release assay results. The very high levels of interferon-gamma in samples stimulated with avian tuberculin and the elevated levels of interferon-gamma in samples stimulated with bovine tuberculin observed in the interferon-gamma release assay can be explained by a simultaneous infection with bovine and avian tubercle bacilli.

The epidemiological assessment of the above findings and conclusions that can be drawn from this assessment regarding further proceedings go beyond the scope of their assessment and interpretation.

The epidemiological assessment of the above findings and conclusions needs further investigation. However, although tuberculosis in European bison is not subject to the statutory obligation of eradication, they may be classified as infected or suspected of infection within the meaning of the provisions of the Act of 11 March 2004 on the health protection of animals and eradication of infectious animal diseases. Similarly, the identification of such animals should be treated as a disease outbreak with all possible consequences for human and animal health.

The anti-tuberculosis treatment of animals, especially free-living animals, raises many controversies, while euthanasia is a generally accepted option (2).

\section{References}

1. Anusz K., Kita J., Zaleska M., Salwa A., Malicka E., Bielecki W., Osinska B.: Some morphological, biochemical and immunological blood parameters in European bison with or without lesions in the digestive, respiratory, urinary and reproductive tracts. Pol. J. Vet. Sci 2007, 10, 137-142.
2. Briones V., de Juan Lucia, Sánchez C., Vela A. I., Galka M., Montero N., Goyache J., Aranaz A., Mateos A., Domínguez L.: Bovine Tuberculosis and the Endangered Iberian Lynx. Emerg. Inf. Dis. 2000, 6, 189-191.

3. Buddle B. M., Livingstone P. G., de Lisle G. W.: Advances in ante-mortem diagnosis of tuberculosis in cattle. New Zeland Vet. J. 2009, 57, 173-180.

4. Gormley E., Doyle M. B., Fitzsimons T., McGill K., Collins J. D.: Diagnosis of Mycobacterium bovis infection in cattle by use of the gamma-interferon (Bovigam) assay. Vet. Microbiol. 2006, 112, 171-179.

5. Instruction of the Chief Veterinary Officer no. GIWpr-02010-8/2016 of 8 February 2016 on proceedings concerning the suspicion and eradication, as well as the performance of control studies of bovine tuberculosis, Warsaw 2016.

6. Kita J., Anusz K.: Diagnosis of tuberculosis in cattle. Życie Wet. 2009, 84, 467-473

7. Krajewska M., Zabost A., Welz M., Lipiec M., Orłowska B., Anusz K., Brewczyński P., Augustynowicz-Kopeć E., Szulowski K., Bielecki W., Weiner M.: Transmission of Mycobacterium caprae in a herd of European bison in the Bieszczady Mountains, Southern Poland. Eur. J. Wildl. Res. 2015, 61, 429-433.

8. Krzysiak M. K., Dackiewicz J., Kęsik-Maliszewska J., Larska M.: Post-mortem evaluation of pathological lesions in European bison (Bison bonasus) in the Białowieża Primeval Forest between 2008 and 2013. Bull. Vet. Inst. Pulawy 2014, 58, 421-431.

9. Krzysiak M. K., Larska M.: Pharmacological immobilization of European bison (Bison bonasus). Med. Weter. 2014, 70, 172-175.

10. Lipiec M., Pilaszek $J$.: Instructions for laboratory diagnostics of bovine tuberculosis. Wydawnictwo PIWet-PIB, Puławy 2007.

11. Miller M., Buss P., Hofmeyr J., Olea-Popelka F., Parsons S., van Helden P. Antemortem Diagnosis of Mycobacterium bovis Infection in Free-ranging African Lions (Panthera leo) and Implications for Transmission. J. Wildl. Dis. 2015, 51, 493-497.

12. Olech W., Bielecki W., Bołbot A., Bukowczyk I., Dackiewicz J., Dymnicka M., Hławiczka M., Krasiński Z., Nowak Z., Perzanowski K., Raczyński J., Tęsiorowski W., Wyrobek K.: European bison breeding. Instructions for captive breeding. European Bison Friends Society, Warsaw 2008, p. 76-79.

13. Orlowska B., Augustynowicz-Kopeć E., Krajewska M., Zabost A., Welz M., Kaczor S., Anusz K.: Mycobacterium caprae transmission to free-living grey wolves (Canis lupus) in the Bieszczady Mountains in Southern Poland. Eur. J. Wildl. Res. 2017, 63, 1-5.

14. Rodriguez-Campos S., Smith N. H., Boniotti M. B., Aranaz A.: Overview and phylogeny of Mycobacterium tuberculosis complex organisms: implication for diagnostics and legislation of bovine tuberculosis. Res. Vet. Sci. 2014, 97, 5-19.

15. Tweedle N. E., Livingstone P.: Bovine tuberculosis control and eradication program in Australia and New Zeland. Vet. Microbiol. 1994, 40, 23-29.

16. Wood P. R., Jones S. L.: BOVIGAM: an in vitro cellular diagnostic test for bovine tuberculosis. Tuberculosis (Edinb.) 2001, 81, 147-155.

Corresponding author: Krzysztof Anusz, DVM, PhD, Prof. SGGW, Nowoursynowska 166, 02-787 Warsaw, Poland; e-mail: krzysztof anusz@ sggw.pl 